\title{
Kreftoverlevere har vansker med å få jobb
}

\section{Overlevende etter kreft er oftere arbeidsløse sammenliknet med den øvrige befolkningen. Det viser en ny Cochrane-analyse.}

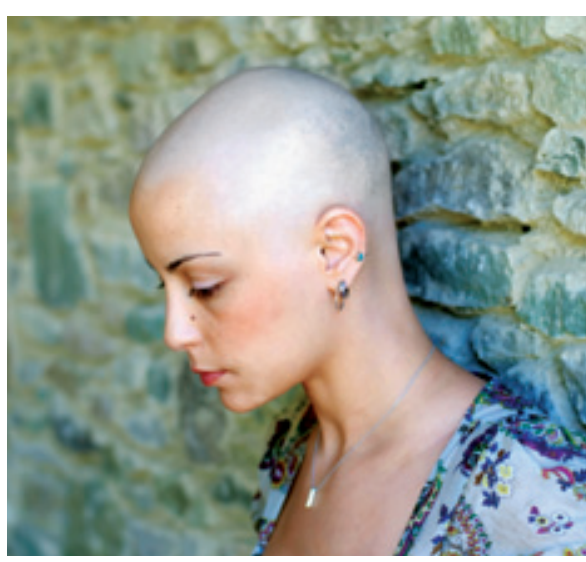

Illustrasjonsfoto Istockphoto
Analysen omfattet randomiserte, kontrollerte studier $(\mathrm{n}=14)$ og kontrollerte før- ogetter-studier $(n=4)$ med fokus på psykologiske, fysiske, medisinske eller multidisiplinære intervensjoner til kreftpasienter med henblikk på arbeidssituasjon. Det var i alt 1652 deltakere (1).

Eneste signifikante funn var at en multidisiplinær intervensjon med både fysiske og psykologiske komponenter førte til at en høyere andel kom tilbake til arbeid (OR $1,87 ; 95 \% \mathrm{KI} 1,07-3,27)$. Verken psykologiske intervensjoner, medisinske interversjoner eller fysisk aktivitet påvirket arbeidssituasjonen signifikant. Det ble ikke funnet påvirkning ved noen av intervensjonene $\mathrm{i}$ forhold til livskvalitet.

Mange kreftpasienter har fortsatte problemer med tretthet, smerter og depresjon, ifølge de nederlandske forfatterne, som mener at en multidisiplinær innsats kan øke andelen pasienter som kommer i arbeid igjen.

- Undersøkelsen dokumenterer at mange kreftpasienter har senfølger av både fysisk, psykisk og sosial art, herunder også vansker med å få tilknytning til arbeidsmarkedet. Dokumentasjonen for hvordan vi best kan hjelpe, er mangelfull, men mye tyder på at hjelpen bør gis over lengre tid og at den skal være flerdimensjonal. Det er stort behov for forskning og utvikling av evidensbaserte hjelpetiltak, slik at flere tidligere pasienter kommer tilbake i arbeid, sier Frede Olesen i Kræftens Bekæmpelse til Ugeskrift for Lager (2).

\section{Erlend Hem}

erlend.hem@medisin.uio.no

Tidsskriftet

\section{Litteratur}

1. De Boer AG, Taskila T, Tamminga SJ et al. Interventions to enhance return-to-work for cancer patients. Cochrane Database Syst Rev 2011; nr. 2: CD007569

2. Høi-Hansen CE. Meget skal til for at øge cancerpatienters chance for at komme i arbejde igen. Ugeskr Læger 2011; 173: 952.

\section{DNA-studier i syndromutredning}

\section{Kromosomale mikrodelesjoner kan gi forsinket utvikling og atferds- problemer.}

Det er velkjent at kromosomale mikrodelesjoner og mikroduplikasjoner kan gi syndromer med medfødte misdannelser, utviklingshemning og dysmorfe trekk. De siste årene har ny teknologi i form av DNA-matriser kunnet påvise slike avvik (1). Mange av avvikene har unike bruddpunkter, men det finnes også grupper av rekurrente avvik (mikrodelesjonssyndromer), f.eks. 15q11.2delesjon.

15q11.2-delesjon er et nylig beskrevet mikrodelesjonssyndrom (2). Flere forskere har antydet en sammenheng mellom 15q11.2delesjon og forsinket utvikling, språkvansker og psykiatrisk sykdom. Vi studerte sju pasienter, fra seks familier, med 15q11.2-delesjon og ulike grader av forsinket utvikling og atferdsproblemer (3). I fem av familiene undersøkte vi både mor og far, og fant at mikrodelesjonen var nedarvet fra en av foreldrene. Fire av foreldrene opplyste om moderate eller mer alvorlige symptomer som lærevansker og atferdsvansker.

Det kan diskuteres om 15q11.2-mikrodelesjon skal ses på som et nytt mikrodelesjonssyndrom med redusert penetrans og variabel ekspressivitet, eller en kopitallvariant med minimal betydning for sykdom. Basert på våre og andres funn kan det se ut som 15q11.2-delesjon har betydning for den mentale utviklingen. Det er ikke kjent hvilket gen eller hvilke gener i delesjonen som eventuelt er av betydning. Tolking av mikrodelesjoner og mikroduplikasjoner kan være vanskelig, og det er viktig at avvik ses i sammenheng med pasientens kliniske symptomer og funn.

\section{Charlotte von der Lippe}

uxhelc@ous-hf.no

Senter for sjeldne diagnoser

Oslo universitetssykehus

\section{Litteratur}

1. Rødningen OK, Prescott TE, Hovland R et al. Påvisning av kromosomavvik ved hielp av DNA-matriser. Tidsskr Nor Legeforen 2010; 130: 944-7.

2. Doornbos M, Sikkema-Raddatz B, Ruijvenkamp CA et al. Nine patients with a microdeletion $15 q 11.2$ between breakpoints 1 and 2 of the Prader-Willi critical region, possibly associated with behavioural disturbances. Eur J Med Genet 2009; 52: 108-15. 15q11.2 microdeletion - seven new patients with delayed development and/or behavioural problems. Eur J Med Genet 2010; doi: 10.1016/ j.ejmg.2010.12.008.
3. von der Lippe C, Rustad C, Heimdal K et al.

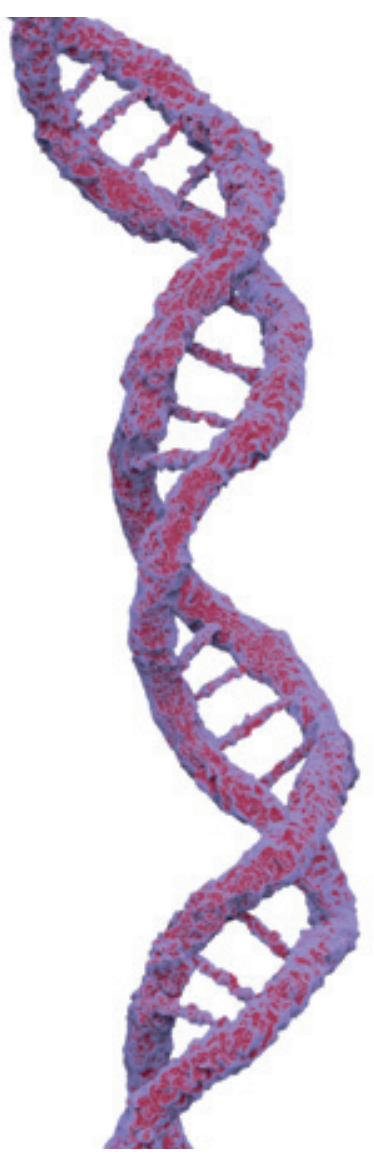

Illustrasjonsfoto SCANPIX 